\title{
Protection of Tomato Seedlings by Pre-treatment with Pseudomonas glumae from Infection with Pseudomonas solanacearum and Its Mechanisms*
}

\author{
Naruto FuruYa**, Yoshiyuki Kushima ${ }^{\dagger}$, Kenichi TsuchiYA ${ }^{\text {t†, }}$ \\ Nobuaki MatSUYAMA** and Satoshi WAKIMOTO**
}

\begin{abstract}
Pseudomonas glumae strains showed different antibiotic activities against $P$. solanacearum depending upon kind of media used. When triphenyl tetrazolium chloride medium (TTC medium) was used, all strains of $P$. glumae formed growth inhibition zones around their colonies on the lawn of $\boldsymbol{P}$. solanacearum used as indicator. Pre-treatment of the roots of tomato seedlings with the suspension of antibiotic productive strains of $P$. glumae suppressed the severity of wilt incited by challenge inoculation with $P$. solanacearum. The disease suppression was positively correlated with length of dipping time and concentration of the bacterial suspension used for pre-treatment. Dipping of the roots of tomato seedlings into the bacterial suspension of $c a .10^{10} \mathrm{cfu} / \mathrm{ml}$ for $24 \mathrm{hr}$ showed highest suppressiveness. The pre-treatment of tomato roots with non-antibiotic-producing strain or heat-killed cells of $P$. glumae also showed protection, suggesting that some mechanisms other than antibiotic productivity were involved in the suppression of the disease.
\end{abstract}

(Received October 2, 1990)

Key words: Pseudomonas solanacearum, Pseudomonas glumae, antibiotic productivity, biological control.

\section{INTRODUCTION}

Bacterial wilt of tomato caused by Pseudomonas solanacearum (Smith 1896) Smith 1914 is one of the most serious diseases of tomato in the world. The causal bacterium can attack not only various solanaceous plants but also many plants belonging to other families ${ }^{11}$. $P$. solanacearum multiplies even under the nutritionally limited conditions such as in soil ${ }^{20,24)}$ and water ${ }^{13,28}$, and survives for many years. Thus, the bacterial wilt of tomato is one of the typical soil-borne diseases ${ }^{1}$. For control the disease, some measures such as cultivation of resistant varieties ${ }^{19)}$, crop rotation every several years, and soil disinfection by chemical application have been recommended. All of these procedures, however, are not sufficiently effective. Some other effective methods have been expected to be developed.

Since successful application of the bacteriocin productive strain K84 of Agrobacterium radiobacter against crown gall of stone fruits ${ }^{15,16}$, the studies on biological methods to control bacterial diseases of plant have been emphasized. Chen and Echandi ${ }^{2,3}$. reported the efficacy

* This work was supported by a Grant-in-Aid for Scientific Research No. 01440008 (1989).

** Faculty of Agriculture, Kyushu University, Fukuoka 812, Japan 九州大学農学部

$\dagger$ Present address: Miyazaki Agriculture Research Center, Sadowara, Miyazaki 880-02, Japan 現在：宮崎総合農業試験場

$\dagger$ Present address: National Institute of Agrobiological Resources, Tsukuba 305, Japan 現在: 農 業生物資源研究所 
of an avirulent bacteriocin-producing strains of $P$. solanacearum on the control of bacterial wilt of tobacco. Tanaka et al. ${ }^{23)}$ also showed that tobacco plants were protected from bacterial wilt with an avirulent strain M4S of $P$. solanacearum and its bacteriophages.

The authors previously demonstrated ${ }^{29)}$ that strains of $P$. glumae Kurita et Tabei 1967, the causal bacterium of grain rot of rice, produced antibacterial substances showing wide activity spectrum against plant pathogenic bacteria including $P$. solanacearum. The efficacy of $P$. glumae strains on the protection of tomato seedlings from infection with $P$. solanacearum and its mechanisms were investigated.

\section{MATERIALS AND METHODS}

Pseudomonas glumae. Forty-seven strains of $P$. glumae shown in Table 1 were used in this experiment. These strains were collected from various localities of Japan and preserved in the Laboratory of Plant Pathology, Kyushu University. Most of these strains were virulent to rice seedlings while some others were avirulent. The avirulent strains were considered to be the mutants which appeared during preservation by means of successive transfers on the medium in the past. These strains were cultured on the slants of PSA medium (decoction of 300 g potato 1 liter, $\mathrm{Na}_{2} \mathrm{HPO}_{4} \cdot 12 \mathrm{H}_{2} \mathrm{O} 2 \mathrm{~g}, \mathrm{Ca}\left(\mathrm{NO}_{3}\right)_{2} 0.5 \mathrm{~g}$, peptone $5 \mathrm{~g}$, sucrose $15 \mathrm{~g}$, agar 15 $\mathrm{g}, \mathrm{pH} 7.0$ ) at $30^{\circ} \mathrm{C}$ for 2 to 3 days, suspended in sterile distilled water at the concentration of ca. $10^{7} \mathrm{cfu} / \mathrm{ml}$ in test tubes, and preserved at $22-25^{\circ} \mathrm{C}$ during this experiment. For long term preservation, the bacteria were lyophilized with PS broth and kept at $4^{\circ} \mathrm{C}$.

The bacterial cells were preliminary grown on the PSA slants at $30^{\circ} \mathrm{C}$ for $48 \mathrm{hr}$, suspended in $10 \mathrm{ml}$ of sterile distilled water, added the suspension to $200 \mathrm{ml}$ of PS broth in Sakaguchi flask, and shaked at $30^{\circ} \mathrm{C}$ for $48 \mathrm{hr}$. The bacterium was harvested by centrifugation at $6,000 \times g$ for $20 \mathrm{~min}$, and resuspended in sterile distilled water at the concentration of $c a .10^{10} \mathrm{cfu} / \mathrm{ml}$. The suspension was diluted 10 and 100 times just before use. Viable cells were counted by plating on PSA medium. Bacterial suspensions thus prepared were used for protecting tomato seedlings from the infection with $P$. solanacearum.

Pseudomonas solanacearum. Of six P. solanacearum strains ${ }^{28)}$ (N6211, N6275, KT-2, $\mathrm{Ku} 7501-1$, Ku7502-1, Ku7601-1), the strain KT-28,29) was used most frequently because of its strongest virulence to tomato plants. These strains suspended in sterile distilled water were maintained at $25-27^{\circ} \mathrm{C}$. Each stock suspension was spread on TTC medium ${ }^{12)}$ (peptone 10 $\mathrm{g}$, casein hydrolysate (Difco) $1 \mathrm{~g}$, glucose $5 \mathrm{~g}$, agar $17 \mathrm{~g}$, triphenyl tetrazolium chloride $(1 \%$ solution) $5 \mathrm{ml}$, distilled water 1 liter), and the plates were incubated at $30^{\circ} \mathrm{C}$ for $48 \mathrm{hr}$ for selecting virulent colonies. Typical virulent colonies were isolated and grown in PS broth on a rotary shaker at $30^{\circ} \mathrm{C}$ for $48 \mathrm{hr}$. Cells were harvested by centrifugation at $6,500 \times g$ for $20 \mathrm{~min}$ and resuspended in sterile distilled water to give concentrations of $c a .10^{8}, 10^{9}$ and $10^{10} \mathrm{cfu} / \mathrm{ml}$ to be used as inoculum. Viable cells were counted by plating method on TTC medium. If the inoculum concentration was lower than $10^{8} \mathrm{cfu} / \mathrm{ml}$, the disease did not occur sufficiently (data not shown).

In vitro antibiotic activity of $P$. glumae to $P$. solanacearum. To assess the antibiotic activity of $P$. glumae to $P$. solanacearum in vitro, the fresh culture of $P$. glumae grown on the PSA slant for 1 to 2 days was spotted at the center or at 3 points keeping distance from one another on the plates of various media such as YPDA ${ }^{29)}$, PSA and TTC medium, in petri dishes $9 \mathrm{~cm}$ in diameter. After incubation at $30^{\circ} \mathrm{C}$ for $72 \mathrm{hr}$, bacterial cells were killed by chloroform vapor as reported previously ${ }^{29)}$. The suspension $(0.2 \mathrm{ml})$ of $P$. solanacearum (conc. ca. $\left.10^{8} \mathrm{cfu} / \mathrm{ml}\right)$ mixed with $5 \mathrm{ml}$ of plain agar $(0.5 \%)$ was poured over the bottom layer, and the plate was incubated at $30^{\circ} \mathrm{C}$ for $48 \mathrm{hr}$. The antibiotic activity was evaluated by measuring the widths of inhibition zones.

Induction of non-antibiotic-producing mutants of P. glumae by NTG treatment. A wild strain of $P$. glumae, N750, was cultured on the YPDA medium containing streptomycin 
sulfate $(500 \mu \mathrm{g} / \mathrm{ml})$ to obtain streptomycin resistant (SR) mutants. The streptomycin resistant parental strain, N750-SR, thus obtained was grown in YPD broth under shaking conditions at $30^{\circ} \mathrm{C}$ for $24 \mathrm{hr}$. The bacterial cells were washed twice in sterile phosphate buffer $(0.067 \mathrm{M}$, $\mathrm{pH} 7.0$ ) by centrifugation. The final pellet was resuspended to make the concentration of $c a$. $10^{7} \mathrm{cfu} / \mathrm{ml}$, which was treated with $N$-methyl- $N^{\prime}$-nitro- $N$-nitroso-guanidine (TNG) at the concentration of $50 \mu \mathrm{g} / \mathrm{ml}$ in the same buffer at $30^{\circ} \mathrm{C}$ for $20 \mathrm{~min}$. After the treatment, cells were washed twice in the same buffer to remove NTG. A part of bacterial suspension was transferred to YPD broth and incubated overnight for multiplication of surviving cells. The culture was then diluted, spread on YPDA plates containing streptomycin sulfate $(500 \mu \mathrm{g} / \mathrm{ml})$ and incubated for 3 to 4 days at $30^{\circ} \mathrm{C}$. Single colonies were isolated and each isolate was measured for antibiotic activity by plating chloroform method using various media containing $P$. solanacearum as indicator. Thus, streptomycin resistant and non-antibiotic-productive strain, N750-SR-NP, was obtained.

Heat-killed cells of P. glumae. The bacterial cells of $P$. glumae strain N750 grown on the slant of PSA medium at $30^{\circ} \mathrm{C}$ for $48 \mathrm{hr}$ were suspended in sterile distilled water (conc. $c a .10^{10} \mathrm{cel} / \mathrm{ml}$ ). The suspension was incubated at $100^{\circ} \mathrm{C}$ for $10 \mathrm{~min}$ in a water bath and used for testing its suppressiveness to tomato wilt.

Tomato plants. To evaluate the suppressiveness of $P$. glumae cells to bacterial wilt, the tomato cultivar Toko was used. The seeds were disinfected by dipping in a solution of $3 \%$ hypochlorite (Antiformin) at room temperature for $15 \mathrm{~min}$, rinsed with tap water, sown on the autoclaved soil in the pots of $10 \mathrm{~cm}$ in diameter, and incubated in the air-conditioned greenhouse at $25-30^{\circ} \mathrm{C}$. Two weeks later, the plants grown up to $10 \mathrm{~cm}$ in height were used.

Pot assay for bacterial wilt suppression. After pulling out the tomato seedlings. their roots were rinsed with tap water and dipped in the suspension of $P$. glumae (conc. $c a .10^{8}$, $10^{9}$ and $10^{10} \mathrm{cfu} / \mathrm{ml}$ ) for a certain period from $10 \mathrm{~min}$ to $24 \mathrm{hr}$ (pre-treatment). The roots thus treated were then dipped in $P$. solanacearum suspension (conc. ca. $10^{8}, 10^{9}$ and $10^{10} \mathrm{cfu} / \mathrm{ml}$ ) for $10 \mathrm{~min}$ (post-inoculation). Each plant thus treated was transplanted in the plastic pot $(6 \times 6 \times$ $4.5 \mathrm{~cm}$ ) containing fertilized nursery soil which was heat sterilized previously. The plants were grown in the air-conditioned greenhouse at $25-30^{\circ} \mathrm{C}$. The soil in the pots was kept uniformly under wet conditions. The disease severity was recorded 5-day intervals on a scale of 0 to 3 , where $0=$ no wilt; $1=1-50 \%$ leaves wilted; $2=$ more than $50 \%$ leaves wilted; $3=$ entire plant wilted or dead.

\section{RESULTS}

\section{Antibiotic activity of $P$. glumae in vitro}

All strains of $P$. glumae used in this study showed antibiotic activity against $P$. solanacearum KT-2 on TTC medium. The activities, however, were different depending upon the kind of media used (Table 1). The antibiotic activity of $P$. glumae exhibited on YPDA medium did not show remarkable variation among six strains of $P$. solanacearum used (data not shown).

\section{Protection efficacy shown by $P$. glumae}

The suppressiveness of the strain N750 of $P$. glumae to bacterial wilt varied depending upon the duration of the dipping for pre-treatment of tomato seedlings. The suppression was slight when seedlings were dipped in bacterial suspension for $10 \mathrm{~min}$, while it increased in parallel with the duration of dipping. When the seedlings were dipped for 12 or $24 \mathrm{hr}$, the control was remarkable (Table 2). The suppressive effect also varied depending upon bacterial concentrations of both pre-tretment and post-inoculation. The effect was the highest at $c a .10^{10} \mathrm{cfu} / \mathrm{ml}$ of $P$. glumae, while it decreased at $10^{8}$ and $10^{9} \mathrm{cfu} / \mathrm{ml}$. When inoculum concentration was $c a$. $10^{8} \mathrm{cfu} / \mathrm{ml}$, the higher suppressive effect was obtained than that with $10^{10} \mathrm{cfu} / \mathrm{ml}$ (Table 3). Although $P$. glumae strains Ku8117, 805, 752, P1-22-4 and YN7825 showed the different extent of antibiotic activity in vitro, they did not show any significant variation in the disease suppres- 
siveness (Table 4). The non-antibiotic-producing strain (N750-SR-NP) also suppressed disease to the same level as that shown by antibiotic producing wild strain (N750) (Table 5). Furthermore, the heat-killed cell suspension of $\boldsymbol{P}$. glumae N750 also showed protection similar to those incited by living bacteria (Table 6).

Table 1. Effect of the media on the formation of growth-inhibition zone by Pseudomonas glumae strains on the lawn of $P$. solanacearum

\begin{tabular}{|c|c|c|c|c|c|c|c|}
\hline P. glumae & YPDA & PSA & TTC & P. glumae & YPDA & PSA & TTC \\
\hline N7401 & -a) & - & + & 8028 & $+t+$ & - & + \\
\hline N7501 & ++ & - & + & 1 & $++t$ & ++ & + \\
\hline N7502 & - & + & $++t$ & 111 & ++ & $+t$ & $++t$ \\
\hline N7503 & + & - & ++ & 2 & $+t+$ & + & ++ \\
\hline N7504 & - & - & ++ & Ku8101 & + & + & ++ \\
\hline N7505 & ++ & ++ & +++ & Ku8102 & + & + & + \\
\hline YN7805 & +++ & - & ++ & Ku8103 & ++ & - & ++ \\
\hline YN7810 & - & ++ & $+t$ & Ku8104 & + & - & + \\
\hline YN7825 & - & + & $t+$ & Ku8105 & $+t$ & ++ & ++ \\
\hline 742 & +++ & - & +++ & Ku8106 & +++ & + & ++ \\
\hline N750 & +++ & - & +++ & Ku8111 & + & + & ++ \\
\hline 752 & + & ++ & +++ & Ku8112 & ++ & $+t+$ & + \\
\hline 805 & +++ & $+t+$ & $+t+$ & Ku8113 & $++t$ & + & +++ \\
\hline 806 & + & ++ & ++ & Ku8114 & +++ & ++ & ++ \\
\hline P1-22-1 & +++ & - & +++ & Ku8115 & + & - & + \\
\hline P1-22-2 & + & - & ++ & Ku8116 & + & ++ & + \\
\hline P1-22-3 & + & - & + & Ku8117 & + & - & + \\
\hline P1-22-4 & + & - & + & Ku8119 & $+t$ & - & + \\
\hline So-1 & $++t$ & - & ++ & Ku8120 & +++ & - & +++ \\
\hline 8001 & + & - & + & $\mathrm{Ku} 8121$ & $++t$ & $++t$ & +++ \\
\hline 8012 & + & + & + & Ku8122 & $++t$ & ++ & ++ \\
\hline 8015 & - & - & ++ & Ku8123 & ++ & + & ++ \\
\hline 8017 & $+t+$ & - & + & Ku8124 & +++ & + & ++ \\
\hline 8020 & + & - & ++ & & & & \\
\hline
\end{tabular}

a) Width of inhibition zone: - not detected, + below $5 \mathrm{~mm},++5-10 \mathrm{~mm},+++$ above $10 \mathrm{~mm}$.

Table 2. Protection of tomato seedlings from bacterial wilt a) by pre-treatment with the suspension of Pseudomonas glumae strain N750

\begin{tabular}{lllll}
\hline \hline \multirow{2}{*}{$\begin{array}{l}\text { Time of } \\
\text { pre-treatment (dipping) }\end{array}$} & \multicolumn{3}{c}{ Disease index c) } \\
\cline { 3 - 5 } & & 10 & 20 & 30 days \\
\hline $10 \mathrm{~min}$ & Treated a) & $1.15 \mathrm{NS} \mathrm{d})$ & $1.85 \mathrm{NS}$ & $2.10 \mathrm{NS}$ \\
& Control b) & 1.10 & 2.00 & 2.15 \\
$60 \mathrm{~min}$ & Treated & $1.30 \mathrm{NS}$ & $2.00 \mathrm{NS}$ & $2.30 \mathrm{NS}$ \\
& Control & 1.05 & 2.00 & 2.20 \\
$12 \mathrm{hr}$ & Treated & $0.05^{* *}$ & $0.15^{* * *}$ & $0.15^{* * *}$ \\
& Control & 1.20 & 2.00 & 2.25 \\
& Treated & $0.00^{* *}$ & $0.15^{* * *}$ & $0.15^{* * *}$ \\
& Control & 1.00 & 1.80 & 2.40 \\
\hline
\end{tabular}

a) Tomato seedlings were pre-treated with a suspension of $P$. glumae $\left(\mathrm{ca} .10^{10} \mathrm{cfu} / \mathrm{ml}\right)$ and inoculated with $P$. solanacearum strain KT-2 $\left(c a .10^{8} \mathrm{cfu} / \mathrm{ml}\right)$ by dipping their roots just after pre-treatment.

b) Sterile distilled water was used instead of a suspension of $P$. glumae in the case of pre-treatment.

c) Disease index based on a scale from 0 , no visible symptom to 3 , entire plant wilted or dead.

d) NS: Not significantly different by paired $t$-test, ***,**: Statistically different by paired $t$-test, $P=$ 0.001 and 0.01 , respectively. 


\section{DISCUSSION}

Non-pathogenic and bacteriocin productive strains of $P$. solanacearum have been reported to be applicable for biological control of bacterial wilt of solanaceous plants caused by $P$. solanacearum ${ }^{2,3,26}$. The mechanism of the suppression of the disease was considered to be the inhibition of the multiplication of pathogenic bacteria by bacteriocin producing non-pathogenic

Table 3. Protection of tomato seedlings from infection of Pseudomonas solanacearum KT-2 by pre-treatment with suspension of $P$. glumae N750

\begin{tabular}{ccccc}
\hline \multirow{2}{*}{\begin{tabular}{c}
$P$. glumae $^{\mathrm{a}}(\mathrm{cfu} / \mathrm{ml})$ \\
\cline { 3 - 4 }
\end{tabular}} & $\begin{array}{l}P . \text { solanacearum } \mathrm{b}) \\
(\mathrm{cfu} / \mathrm{ml})\end{array}$ & 10 & 20 & 30 days \\
\hline $10^{8}$ & $10^{8}$ & $0.65 \mathrm{~B} \mathrm{~d})$ & $0.60 \mathrm{BD}$ & $0.95 \mathrm{BC}$ \\
$10^{9}$ & $10^{8}$ & $0.50 \mathrm{~B}$ & $0.50 \mathrm{CD}$ & $0.75 \mathrm{C}$ \\
$10^{10}$ & $10^{8}$ & $0.15 \mathrm{~B}$ & $0.15 \mathrm{D}$ & $0.15 \mathrm{C}$ \\
0 & $10^{8}$ & $1.45 \mathrm{~A}$ & $1.90 \mathrm{~A}$ & $2.10 \mathrm{~A}$ \\
\hline $10^{8}$ & $10^{10}$ & $1.35 \mathrm{~A}$ & $1.60 \mathrm{~A}$ & $1.85 \mathrm{AB}$ \\
$10^{9}$ & $10^{10}$ & $1.05 \mathrm{~A}$ & $1.70 \mathrm{~A}$ & $1.75 \mathrm{AB}$ \\
$10^{10}$ & $10^{10}$ & $0.90 \mathrm{~B}$ & $1.10 \mathrm{ABC}$ & $1.05 \mathrm{BC}$ \\
0 & $10^{10}$ & $1.35 \mathrm{~A}$ & $1.90 \mathrm{~A}$ & $2.10 \mathrm{~A}$ \\
\hline
\end{tabular}

a) Pre-treatment for $24 \mathrm{hr}$.

b) Dip inoculation for $10 \mathrm{~min}$.

c) Disease index based on a scale from 0 , no visible symptom to 3, entire plant wilted or dead.

d) Within columns, means with the same letter are not significantly different $(P=0.05)$ according to the Duncan's multiple range test.

Table 4. Protection of tomato seedlings from bacterial wilt by pre-treatment with the suspension of various Pseudomonas glumae strains

\begin{tabular}{llcc}
\hline \multirow{2}{*}{$\begin{array}{l}P . \text { glumae a) } \\
\text { (strain) }\end{array}$} & \multicolumn{1}{c}{ Disease index $\mathrm{b}$ ) } \\
\cline { 2 - 4 } & 5 & 15 & 30 days \\
\hline Ku8117 & $0.00 \mathrm{~B} \mathrm{c)}$ & $0.33 \mathrm{~B}$ & $0.50 \mathrm{~B}$ \\
805 & $0.20 \mathrm{~B}$ & $0.80 \mathrm{~B}$ & $0.93 \mathrm{~B}$ \\
752 & $0.00 \mathrm{~B}$ & $0.39 \mathrm{~B}$ & $0.67 \mathrm{~B}$ \\
P1-22-4 & $0.00 \mathrm{~B}$ & $0.44 \mathrm{~B}$ & $0.50 \mathrm{~B}$ \\
YN7825 & $0.27 \mathrm{~B}$ & $0.80 \mathrm{~B}$ & $0.87 \mathrm{~B}$ \\
Control & $2.20 \mathrm{~A}$ & $3.00 \mathrm{~A}$ & $3.00 \mathrm{~A}$ \\
\hline
\end{tabular}

a) The roots were dipped in the suspension of $c a .10^{10} \mathrm{cfu} / \mathrm{ml}$ for $24 \mathrm{hr}$.

b) Disease index based on a scale from 0 , no visible symptom to 3 , entire plant wilted or dead.

c) Within columns, means with the same letter are not significantly different $(P=0.05)$ according to the Duncan's multiple range test.

Table 5. Effect of the non-antibiotic-producing mutant (N750-SR-NP) of P. glumae on the protection of tomato seedlings from bacterial wilt

\begin{tabular}{lcccc}
\hline \hline \multirow{2}{*}{ Strain a) } & $\begin{array}{c}\text { Antibiotic } \\
\text { productivity }\end{array}$ & 5 & 15 & Disease index b) \\
\cline { 3 - 5 } & + & $0.00 \mathrm{~B}(\mathrm{c})$ & $0.35 \mathrm{~B}$ & 30 days \\
\hline N750 & - & $0.00 \mathrm{~B}$ & $0.90 \mathrm{~B}$ & $0.90 \mathrm{~B}$ \\
N750-SR-NP & & $1.55 \mathrm{~A}$ & $2.85 \mathrm{~A}$ & $3.00 \mathrm{~A}$ \\
Control & & &
\end{tabular}

a) The roots were dipped in the suspension of $c a .10^{10} \mathrm{cfu} / \mathrm{ml}$ for $24 \mathrm{hr}$.

b) Disease index based on a scale from 0 , no visible symptom to 3, entire plant wilted or dead.

c) Within columns, means with same letter are not significantly different $(P=0.05)$ according to the Duncan's multiple range test. 
Table 6. Effect of the heat-killed cells of $P$. glumae N750 on the protection of tomato seedlings from bacterial wilt

\begin{tabular}{llcc}
\hline \hline & \multicolumn{3}{c}{ Disease index ${ }^{\mathrm{b})}$} \\
\cline { 2 - 4 } Pre-treatment a) & 5 & 15 & 30 days \\
\hline Living bacteria & $0.00 \mathrm{~B} \mathrm{c}$ & $0.56 \mathrm{~B}$ & $0.67 \mathrm{~B}$ \\
Heat-killed bacteria & $0.00 \mathrm{~B}$ & $0.77 \mathrm{~B}$ & $0.87 \mathrm{~B}$ \\
Water control & $0.91 \mathrm{~A}$ & $2.73 \mathrm{~A}$ & $2.78 \mathrm{~A}$ \\
\hline
\end{tabular}

a) Pre-treatment for $24 \mathrm{hr}$.

b) Disease index based on a scale from 0 , no visible symptom to 3, entire plant wilted or dead.

c) Within columns, means with same letter are not significantly different $(P=0.05)$ according to the Duncan's multiple range test.

bacteria ${ }^{3)}$.

A matter of great interest in the characteristics of $P$. glumae is the productivity of antibiotics which inhibit growth of various plant pathogenic bacteria including $P$. solanacearum $^{29}$. In this experiment, we found that the antibiotic productivity varied depending upon bacterial strains and the kind of media used. However, all strains of $P$. glumae showed antibiotic activity against $P$. solanacearum on TTC medium in vitro.

The productivity of antibiotics effective to $P$. solanacearum leads us to make an attempt to use $P$. glumae as an agent for biological control. Dipping the roots of tomato seedlings in a suspension of $P$. glumae just before inoculation with $P$. solanacearum showed a remarkable disease suppression. The efficacy of suppression varied with concentrations of $P$. glumae used for pre-treatment and post-inoculation and duration of dipping for pre-treatment.

With regard to the mechanisms of the disease suppression by biological agents, many reports attributed it to antibiotic activity of antagonists ${ }^{6-10,17,25,27,30)}$, contrasting to other results $^{4,5,18,21)}$. Tanaka ${ }^{22)}$ revealed that tobacco and tomato plants treated with heat-killed cells of $P$. solanacearum suppressed bacterial wilt. Kempe et al. ${ }^{14)}$ demonstrated that the induced resistance by pre-treatment with pseudomonads may be involved in the mechanism of suppression of bacterial wilt of potato. To investigate the mechanisms of disease suppression, non-antibiotic-producing mutant of $P$. glumae (N750-SR-NP) induced by NTG treatment and heatkilled bacterial cells were used. The fact that both non-antibiotic-producing living bacteria and heat-killed bacteria suppressed disease severity as in the case of antibiotic producing viable wild strain, suggesting that the role of antibiotic produced by $P$. glumae seems to be slight in the mechanisms of disease suppression. Further studies are needed to clarify the mechanisms in detail.

\section{Literature cited}

1. Buddenhagen, I.W. and Kelman, A. (1964). Biological and physiological aspects of bacterial wilt caused by Pseudomonas solanacearum. Ann. Rev. Phytopathol. 2: 203-230.

2. Chen, W., Echandi, E. and Spurr, H.W., Jr. (1981). Protection of tobacco plants from bacterial wilt with avirulent bacteriocin-producing strains of Pseudomonas solanacearum. In Proc. Fifth Int. Cont. Plant Path. Bact., Cali. pp. 482-492.

3. Chen, W.Y. and Echandi, E. (1984). Effect of avirulent bacteriocin-producing strains of Pseudomonas solanacearum on the control of bacterial wilt of tobacco. Plant Pathol. 33: 245-253.

4. Cooksey, D.A. and Moore, L.W. (1980). Biological control of crown gall with fungal and bacterial antagonists. Phytopathology 70: 506-509.

5. Cooksey, D.A. and Moore, L.W. (1982). Biological control of crown gall with an agrocin mutant of Agrobacterium radiobacter. Phytopathology 72: 919-921.

6. Cook, R.J. (1985). Biological control of plant pathogens: theory to application. Phytopathology 75: 25-29. 
7. Homma, Y. and Suzui, T. (1989). Role of antibiotic production in suppression of radish dampingoff by seed bacterization with Pseudomonas cepacia. Ann. Phytopath. Soc. Japan 55: 643-652.

8. Howell, C.R. and Stipanovic, R.D. (1979). Control of Rhizoctonia solani on cotton seedlings with Pseudomonas fluorescens and with an antibiotic produced by the bacterium. Phytopathology 69: 480-482.

9. Howell, C.R. and Stipanovic, R.D. (1980). Suppression of Pythium ultimum-induced damping-off of cotton seedlings by Pseudomonas fluorescens and its antibiotic, pyoluteorin. Phytopathology 70: 712-715.

10. Howell, C.R. and Stipanovic, R.D. (1983). Gliovirin, a new antibiotic from Gliocladium virens, and its role in the biological control of Pythium ultimum. Can. J. Microbiol. 29: 321-324.

11. Kelman, A. (1953). The bacterial wilt caused by Pseudomonas solanacearum. North Carolina Agr. Expt. Sta. Tech. Bull. 99: 1-194.

12. Kelman, A. (1954). The relationship of pathogenicity of Pseudomonas solanacearum to colony appearance on a tetrazolium medium. Phytopathology 44: 693-695.

13. Kelman, A. (1956). Factors influencing viability and variation in cultures of Pseudomonas solanacearum. Phytopathology 46: 16-17.

14. Kempe, J. and Sequeira, L. (1983). Biological control of bacterial wilt of potatoes: attempts to induce resistance by treating tubers with bacteria. Plant Dis. 67: 499-503.

15. Kerr, A. (1972). Biological control of crown gall: seed inoculation. J. Appl. Bacteriol. 35: 493497.

16. Kerr, A. and Htay, K. (1974). Biological control of crown gall through bacteriocin production. Physiol. Plant Pathol. 4: 37-44.

17. Kloepper, J.W. and Schroth, M.N. (1981). Relationship of in vitro antibiotics of plant growthpromoting rhizobacteria to plant growth and the displacement of root microflora. Phytopathology 71: $1020-1024$.

18. Lindow, S.E. (1985). Integrated control and role of antibiosis in biological control of fire blight and frost injury. In Biological Control of the Phylloplane (Windels, C.E. and Lindow, S.E. eds.). American Phytopathological Society, St. Paul. pp. 83-115.

19. Matsuda, T. (1977). Fundamental studies on the breeding of bacterial wilt resistant varieties in tobacco. Bull. Utsunomiya Tobacco Expt. Sta. 15: 1-90.

20. Okabe, N. (1971). Population changes of Pseudomonas solanacearum and soil microorganisms in artificially infested natural soil. Rev. Plant Protec. Res. 4: 105-108.

21. Rovira, A.D. and Wildermuth, G.B. (1981). The nature and mechanisms of suppression. In Biology and Control of Take-All (Asher, M.J.C. and Shipton, P.J. eds.). Academic Press, London. pp. 385-415.

22. Tanaka, H. (1983). Protection of tobacco and tomato against root infection of Pseudomonas solanacearum by heat-killed bacterial cells. Ann. Phytopath. Soc. Japan 49: 66-68.

23. Tanaka, H. (1990). Control of tobacco bacterial wilt by an avirulent strain of Pseudomonas solanacearum M4S and its bacteriophage. Ann. Phytopath. Soc. Japan 56: 243-246.

24. Tanaka, Y. and Noda, N. (1973). Studies on the factors affecting survival of Pseudomonas solanacearum E.F. Smith, the causal agent of tobacco wilt disease. Bull. Okayama Tobacco Expt. Sta. 32: 81-91.

25. Thomashow, L.S. and Weller, D. (1988). Role of a phenazine antibiotic from Pseudomonas fluorescens in biological control of Gaeumannomyces graminis var. tritici. J. Bact. 170: 3499-3508.

26. Trigalet, A. and Trigalet-Demery, D. (1990). Use of avirulent mutants of Pseudomonas solanacearum for the biological control of bacterial wilt of tomato plants. Physiol. Mol. Plant Pathol. 36: 27-38.

27. Utkhede, R.S. and Rahe, J.E. (1983). Interactions of antagonist and pathogen in biological control of onion white rot. Phytopathology 73: 890-893.

28. Wakimoto, S., Utazu, I., Matsuo, N. and Hayashi, N. (1982). Multiplication of Pseudomonas solanacearum in pure water. Ann. Phytopath. Soc. Japan 48: 620-627.

29. Wakimoto, S., Hirayae, K., Tsuchiya, K., Kushima, Y., Furuya, N. and Matsuyama, N. (1986). Production of antibiotics by plant pathogenic pseudomonads. Ann. Phytopath. Soc. Japan 52: 835842.

30. Xu, G.-W. and Gross, D.C. (1986). Selection of fluorescent pseudomonads antagonistic to Erwinia carotovora and suppressive of potato seed piece decay. Phytopathology 76: 414-422. 


\section{和 文 摘 要}

古屋成人・櫛間義幸・土屋健一・松山宣明・脇本 哲：イネもみ枯細菌病菌（Pseudomonas glumae）飞よ るトマト青枯病の発病抑制とその機作

イネもみ枯細菌病菌のトマト青枯病菌に対して示す抗菌活性は供試する培地の種類によって異なり, TTC 培地上ではすべてのイネもみ枯細菌病菌株がトマト青枯病菌に対して阻止帯を形成した。抗菌物質産生性の イネもみ枯細菌病菌株の懸濁液でトマト幼苗の根部を浸漬処理することによって青枯病の発病が抑制された。 この発病抑制効果と浸漬処理時間および浸漬処理に用いた細菌懸濁液の濃度との間には高い相関が認められ た。トマト幼苗の根部を濃度約 $10^{10} \mathrm{cfu} / \mathrm{ml}$ のイネもみ枯細菌病菌䯚濁液中へ 24 時間浸漬した場合に最も 高い抑制効果が得られた。この発病抑制効果は抗菌物質非産生菌株招よび熱処理死菌によっても認められ, イネもみ枯細菌病菌の産生する抗菌物質以外の要因もこの発病抑制効果の機作に強く関与していることが明 らかとなった。 